\title{
Corruption and Its Eradicate Strategies
}

\author{
Hendrarto \\ hendrarto2020@gmail.com \\ Faculty of Social and Political Sciences, Tidar University, Magelang, Indonesia
}

\begin{abstract}
The Effort to eradicate corruption in Indonesia have actually been done for a long time, namely during the age of corruption itself. Since Indonesia was independent from Dutch colonialism, corruption eradication in Indonesia can be divided within 3 periods, namely during the old order, the new order and the reform order. However, until now it has not been said to be successful, this can be seen from the order of Indonesia that remains low in the eradication of corruption around the world. The strategies used in this case include institutional hesitant strategies. Because less effective than the necessity to be another, tougher strategy to overcome it. One strategy that fits with Indonesia's current situation and condition is to use a hard and radical strategy, namely determined institutional strategy. By using that strategy, it is intended being able to take systematic and coordinated actions, in order to detect and punish corruptors, while also looking for the cause of corruption. This way Indonesia will be able to solve the problem of corruption faced.
\end{abstract}

Keywords: Corruption; Eradication; Strategies; Indonesia; and 3 Periods

\section{Introduction}

We are certainly familiar with the term of corruption, which is a violation of the ethical standards society, which in the last three decades has been plague in our country. Corruption is an extraordinary crime that can damage country's economy growth. Massive corruption crimes can also hinder the country's economic growth, and it is uncommon for society and the country to fall to the brink of poverty.

As we know that long time an ago, there were many cases that have "shaken" all occupations in Indonesia, namely with many major cases of corruption that are very detrimental to the state. One of them are the fugitive key witness named Harun Masiku in the corruption case of Electoral Commission members, as well as the escape of corruptor Djoko Tjandra in the case of Bank Bali. Although it has now been recaptured, there is also a case of Electronic Residential Identity Card (E- KTP) with suspected Chairman of the House Representatives named Setyo Novanto with state losses reaching 2.7 trillion rupiah. The entry of Constitutional Court Chief named Patrialis Akbar to prison for corruption, as well as the imprisonment of the Chairman of the Regional Leadership Council a time ago, the end of corruption in the reclamation of Jakarta Bay. The case of Sumber Waras Hospital in Jakarta, and several years ago that was very tumultuous with the case of tax evasion and bribery by Gayus Tambunan. The tax office employee of group IIIa whose has a wealth account with a value of 125 billion rupiah, have a house and luxury apartment as well as three luxury cars. The case also drags on the number of law enforcement officers involved, both in the Police; Prosecutor and Courts as well as the community itself and in the businesspersons. 
Besides, we still remember and know together about the horrendous Bank Century scandal, thus forcing the House of Representatives to form Special Inspectors of Bank Century to uncover this case, as well as Bank Indonesia Liquidity Assistance (BLBI) case. In addition, almost 50\% more Regional Heads in Indonesia are involved in corruption cases are already suspects, and most have gone to prison. However, in reality until now there has been no concrete and thorough resolution and tend to be ignored and cover each other, so that the public seems compelled and accepting to forget the case. They do not mention many other major corruption cases that have not been revealed at all in the center and region due to the syndicate and mafia law and manipulating both in executives, legislative and law enforcement. They cooperate with rogue/black businesspeople as in the case of Djoko Tjandra with the case of Bank Bali which has recently horrendous our nation.

Corruption in Indonesia, especially in the reform era as it is today tends to develop systemically and massive, as it is considered no longer a violation of the law or an ethical violation. Rather considered a common, reasonable and cultural thing in our society, so it is not surprising that in all research on corruption comparison between countries, Indonesia always occupies a low position in the eradication of corruption.

The practice of corruption at the government and bureaucratic level has actually existed since before the independence era. It even increased during Suharto's presidency from 1967 to 1998. The government's measures to eradicate corruption in the following years have varying effectiveness. However, until now Indonesia still suffers from the practice of bribery and bribery both at the national, provincial and district/ city levels. Transparency International, a global network nonprofit that fights corruption, releases a regular index of perceptions of the world's corruption annually. In 2018, Indonesia was ranked 89th out of 180 countries assessed for its level of corruption. 1 ranking which means net without corruption occupied Denmark. 180 are occupied by Somalia, which means the highest level of corruption. It can also be seen the most recent data from PERC (Political and Economic Risk Consultancy) based in Hong Kong which shows that Indonesia is the most corrupt country out of 16 investment destinations in the Asia Pacific region, this is certainly very concerning for all of us as young generation. Similarly, we see from the 2017 Presidential Staff Office data shows that amount 1,441 corruption cases, 44 percent of corruption cases came from civil servants. The second most convicted is private at 26 percent. Then 2 percent of convicts came from independent institutions and 3 percent from regional heads.

In developing countries, including Indonesia, corruption has become increasingly permeable to all levels, "the greater level and position, the greater level of corruption committed". In addition, this can be considered an acute and difficult social cancer to cure, although it can actually be overcome and eradicated in radical ways and public support as it is done in Korea, Taiwan, China, Singapore, Malaysia and others. These countries, it can be said, are successful enough to eradicate corruption in a hard way, systematically and supported by all societies. In Indonesia, the Government, either through moral warnings, legal actions, or administrative actions, takes many actions but it turns out that they are not effective enough to overcome them. In addition, many provisions and regulations of legislation made and established by the government to address this corruption problem, but it does not seem to be effective to address corruption significantly. The provisions and regulations include as follows:

1. [1] mentioned about Clean State Organizers and Free from Corruption, Collusion and Nepotism

2. [2] mentioned about Clean State Organizers and Free from Corruption, Collusion and Nepotism 
3. [3] mentioned about Eradication of Corruption Crimes which is further enhanced by [4] relating the revision of [3] about corruption eradication

4. [5] mentioned about money laundry crime

5. [6] mentioned about the Establishment of the State Organizer's Wealth Inspection Commission and the Secretariat General of the State Organizer's Wealth Inspection Commission.

Indonesia Government since decades ago has actually demonstrated its commitment in eradicating corruption, but until now there has not been a significant correlation in the corruption eradication, this is because although many rules and regulations but still weak in every action or execution. This is also conveyed by Coordinating Ministry for Political, Legal, and Security Affairs named Mahfud MD stated that one of the indicators is a number of verdicts against corruption case defendants that are judged increasingly light days (Kompas.com, 9/12/2019). In addition, it also began to weaken the institution of corruption eradicating so that it could not be strong and maximal in doing its job. This is also not separated from the agreement struck between the executive and the legislature in reducing the fundamentals and authority of Corruption Eradication Commission as set out in [7] on the second amendment of [8] concerning Corruption Eradication Commission. Thus, then we should need to ask what exactly happened? What kind of corruption phenomenon is happening in Indonesia? Moreover, how does the coping strategy? This condition, will discussed and put forward in this paper, in hopes of making alternatives to make solutions in this beloved country of Indonesia.

\subsection{Literature Review}

\section{Corruption's meaning}

The notion of corruption evolves by so many definitions. This is because the definition of corruption can be either found in various perspectives, through the literal meaning of the word, the opinions of various experts, or based on the legislation governing it. Internationally there is not a single definition as the only reference around the world on what corruption means.

The definition of corruption quoted from [9] stated that corruption comes from the Latin words corruptio or corruptus. While the term corruption in English is corruption and corrupt, in French corruption and in Dutch corruptie which becomes the word corruption in Indonesian? [10] in the Black's Law Dictionary described corruption as an act committed with the intention of giving some advantages contrary to the duties and rights of others. The actions of an official or a trustee, who is contrary to the law, falsely use his power to profit for himself or for others, contrary to the duties and rights of others.

In the Great Dictionary of Bahasa Indonesia (KBBI) explained about the definition of corrupt terms (adjectives) and corruption (nouns). Corrupt is bad, broken, and rotten. Another corrupt meaning is to like to use the goods (money) entrusted to; (using its power for personal gain). Corruption is damaging, embezzling goods (money) belonging to the company (state) of its workplace. Corruption is misappropriation or misuse of state money (corporations and so on) for personal gain or others. Corruption is deviation or embezzling (money and so on). According to the Oxford Dictionary, corruption is dishonest or illegal behavior, especially per committed by the person in authority. Another meaning of corruption is the act or effect of making a person change from a standard of moral behavior to immoral. 
The notion of corruption under regulation of [11] was an act of a person, who with or for committing a crime or is committed by abusing the use of office or position. The understanding of corruption according to [3] on the Eradication of Corruption Crimes. It means that corruption is any person, who is categorized against the law, commits acts of enriching, benefiting their shelf or others or a corporation, abusing the authority or opportunities or facilities that exist because of their office or position could harm the finances of the state or country's economy. While the definition of corruption according to [12] was an act against the law with the intention of enriching one's own, others, or corruption that harms the state or the economy's State.

Bases on the above definitions of corruption, it can be concluded that in general corruption is a bad act or crimes because of abuse of authority, money embezzlement, bribes receipt and so on to enrich itself or others as well as corporations, resulting in financial losses to the state.

\section{Corruption Phenomenon in Indonesia}

Bases on the results of transparency international survey shows Indonesia's Corruption Perceptions Index (GPA) is at level 38 of the scale of $0-100$ in 2018. The index is close to 0 indicating there is still a lot of corruption, instead getting closer to 100 cleaner than corruption. With this score Indonesia was ranked 89th out of 180 countries surveyed. Meanwhile, based on Indonesia Corruption Watch (ICW) data, law enforcement officials as spearheads in eradicating corruption have handled 454 cases throughout 2018. The crackdown on corruption committed by law enforcement in four years (2015-2018) has decreased. Both in the number of cases and actors are designated as suspects. The average case of alleged corruption handled by law enforcement in 2015-2018 was 392 cases with the number of suspects reaching 1,153 people and state losses amount 4.17 trillion rupiah a year. The most stabbings were recorded in 2017 , reaching 576 cases with 1,298 suspects.

Various studies show, corruption or similar acts (collusion, manipulation, nepotism, etc.) can lead to a hamper in people's welfare levels. This Research also shows that no country in the world can prosper if ruled by a corrupt government. The corruptors have deprived society's right of a country to live a comfortable life, by draining their country's wealth or to the extreme; we can call "robbing" the wealth's state. More concerning, many cases in Indonesia also occur in all corners of the village, such as in the case of village chiefs who corrupt County Bank Money known as Bangdes, IDT funds, village funds, even Cash Direct Fund (BLT) and Poverty Rice Fund known as Raskin.

The severe is corruption, so it can be said that every project must occur corruption, both big and small. In fact, aid to victims of disasters becomes a project to be corrupted by officers or officials. For example in the case of corruption was occurring in Nias tsunami disaster of relief fund, North Sumatra in 2006-2008. Then, the case of Unofficial Fund of natural disaster fund was occurring in Mataram, West Nusa Tenggara. There are also cases of corruption in the development of drinking water supply system (SPAM) in disaster areas in Donggala, Palu, and Central Sulawesi. Similarly, corruption cases are mosque rehabilitation in West Nusa Tenggara, and others.

If we want to observe more deeply, then it can be concluded that in the bureaucracy in developing countries such as Indonesia, a very prominent problem is the absence of one's loyalties to a small group of people. Most officials have clicks/groups, whose members only interact with their fellow group members in looking for profit. Likewise, position, such as private property that can be used for personal gain and clicks. These Positions can be used to violate formal regulations, in order to profit, to exploit subordinates for personal gain. The Superiors in bureaucracy tend to hide and protect violations or crimes committed by group's members. This can happen, because for some reason, among others, the employee's salary is felt 
to be lacking, so it is not able to support the desire of family life. There is excessive discretion in the bureaucratic structure, and institutional control is severely lacking, because it does not function as it should and is mentally weak individuals and low empathy towards fellow children of the nation, especially poverty society. This can be a syndicate or mafia that is legal, formal, uniformed whose has great authority to trick the public.

Society especially in new order era used to assume that bureaucracy was seen as the law, and the community should follow the speech of bureaucracy. While society's conditions now tend to be unstable and easily provoked, there is less trust in the government in applying the law fairly, in order, there is less or even no legal certainty, the public knows less about ever increasing rules and regulations. In addition, today's reform era, the Government often implements discriminatory policies, likes to live its group norms / clicks (syndicates), its factions, or its party than existing legal norms, as well as because of the moral or mental degradation of society as a whole. It is this kind of phenomenon gnaws and haunts our country, which will always be the latent factor that damages the nation's joints in an effort to improve society's well-being. Thus, there needs to be appropriate measures, strategies, and complements.

\section{Corruption Eradication Strategy}

The Efforts to eradicate corruption have actually been carried out for a long time, namely during the age of corruption itself. Since Indonesia was independent from Dutch colonialism, the corruption eradication in Indonesia can be divided within 3 periods, namely during the old order, the new order and the reform order. The old order was marked by the emergence regulation of [11] due to the large number of corruption cases with the nationalization of Dutch and foreign companies in Indonesia in 1958, corruption in PERTAMINA, sugar corruption cases allegedly committed by Colonel Suharto, and others. In the new order with the emergence regulation of [13] in corruption eradication, especially corruption that began from the army's control over strategic businesses as well as great authority over bureaucratic officials and supported politically by Golkar party.

In the current reform era, the rule of law on the of corruption eradication is better, among others, with the implementation of [3] and [12] as well as the establishment of an independent corruption eradication agency namely Corruption Eradication Commission. Moreover, many cases have begun to be dismantled and the perpetrators put in jail, but there are still more and larger cases of corruption that escape the legal deterrent. Moreover, with the change of the new law of Corruption Eradication Commission. It is namely the regulation of [14] on Corruption Eradication Commission Crimes, thus causing corruptors to escape the legal deterrent.

\section{Finding and Discussion}

According to [15], in Indonesia there were several reasons corruption eradication is not successful. First, the number of Indonesian rulers who do not commit corruption has become thinner. This happens in all agencies executive, legislative and judicial as our supporters and law enforcement. Second, because there is still discretion in resolving the problem of corruption outside the law, in the form of a refund-darkened amount of money without having to confront the suspect in the lawsuit. It is still coupled with the lightness of punishment for the corruptors so that they do not feel deterred by such disrespectful actions.

Regardless of that opinion, efforts to eradicate corruption in various countries can be grouped into four strategies. Each strategy, illustrates the nature of government commitment 
and preference on one type of anticorruption measure drafted and implemented. If the criterion are strong but the implementation is weak, it is called hesitant. Similarly, if the criteria are weak but the implementation is strong, it is also called hesitant. If the criterion and implementation are equally strong, it is categorized (determined). Environmental criterion, emphasize on moral and social aspects and activities such as moral awareness movements, public awareness projects, programs to cultivate moral values among youth, and so on.

The four strategies used to combat corruption, can briefly be explained as follows: First, the hesitant environmental strategy, characterized by a high level of emotional commitment to efforts in reducing corruption. That strategy is unconstitutional, in the sense takes place outside the framework of a modern bureaucracy that is constitutionally legal, highly ideologically philosophical. Second, determined environmental, a better planned and integrated strategy. Its nature and focus remain the same as the first strategy, which is to emphasize aspects of values and morals with a focus on increasing the moral awareness of individuals, groups, and society entirely about the effects of corrupt behavior. The weakness of both strategies is that only places moral, societal, and extra-legal and non-bureaucratic measures.

Third, institutional hesitant is a strategy that emphasizes institutional size. The goal is to establish anticorruption laws, establish offices or bureaus that accommodate public complaints to combat corruption, implement anticorruption campaign programs and education programs through the mass media. Fourth, an institutionally determined strategy, which is characterizes systematic and coordinated measures to detect and punish corrupt behavior or reduce the source/cause of corruption. In that strategy, the ruling class was driven by the social environment to create constitutional, organizational, and procedural measures to eliminate corruption. The anti-corruption measures in that strategy are more consistent, permanent, and coercive (sanctions or harsh penalties). The strategy includes the establishment of an independent anticorruption body, comprising the executive, legislative, and judiciary; an incentive and punitive system that expressly. These are demands the implementation of anticorruption measures, an open system of government with as little administrative discretion as possible; systematic efforts to reform systems, procedures, and practices to reduce corrupt practices, and free mass media [16].

Bases on these four strategies, if you look at the indications and the current situation and conditions in Indonesia, it can be concluded that the strategy used in the country belongs to the institutional hesitant type. It can be seen, that in Indonesia there are many anticorruption laws, namely [11], [13] concerning on the Eradication of Corruption Crimes, and [3], [4]. In addition, there are also many institutions are handle and supervise in the corruption eradication, such as The Tastipikor Team, Corruption Eradication Commission, Police, Prosecutors, CPC, BPKP, Unofficial Fund (Pungli) eradication team, NGOs such as ICW and others. There are also urged from the public, community leaders, clergy and from the Government, which essentially prohibits acts of corruption accompanied by sanctions and punishments, and is supported by Government policies such as inherent surveillance, and so on.

However, what we see and feel today?, corruption is getting worse, rampant everywhere and in almost all sectors, including in departments considered "white" even as the Ministry of Religious Affair. It happens because all the signs that have been made together are just signs. The law is just a rule of play, not grounded, without concrete realization and not firmly applied, inconsistent with the rules or laws made, because it still looks at the position and position of the bureaucrat. Thus the implementation clearly is still going on "Cut down select" and "The law only applies loudly to small but mushy people to corrupt officials / businessmen". And lately even worse, namely the establishment of a crackdown on corruption eradication institutions through [14] on Corruption Eradication Commission. 
The institutions that handle and supervise the corruption eradication, only supervise it without any authority to complete it, except Corruption Eradication Commission, which is able to become an institution that can be expected to be able to solve until the completion of corruption cases in Indonesia. However, in its implementation it is only able to handle cases that are in the public spotlight, whose value is above 1 billion rupiah, besides, that there is still a cut of the vote according to political order and the interests of the government. Thus, this leads to public distrust of these institutions, especially law enforcement (Police, Prosecutors, Courts and Corruption Eradication Commission) as well as existing laws and regulations, in the seriousness of the Government's handling of corruption issues.

The encouragement from all parties, including clergy, seems to be no longer able to stem the tide of corruption. It shows that the strategy used in Indonesia in eradicating corruption to date is unsuccessful and ineffective. Thus, there needs to be a new alternative solution, which is effectively able to eradicate corruption in Indonesia, one of which is by replacing the current strategy. One strategy that fits with Indonesia's current situation and condition is to use a hard and radical strategy, namely determined institutional strategy.

By using that strategy, it is intended to be able to take systematic and coordinated actions, in order to detect and punish corruptors, while also looking for the cause of corruption. This is because many of the systems implemented in Indonesia provide opportunities for corruption crimes. A good system is able to minimize the crime of corruption. Therefore, it is necessary to improve the system in the following ways such as:

A. Encouraging transparency of state organizers

B. Providing recommendations to the relevant ministries and institutions to take corrective measures

C. Modernizing public services with online and integrated surveillance systems to be more transparent and effective

Institutionally, special and harsh anticorruption laws are required, which contain clear, unequivocal and harsh penalties regardless of position and position in the bureaucracy or in government. For example, as executed in China by applying the death penalty for those who commit corruption and are proven legally above 10 Billion Rupiah, the death penalty can be carried out, above 1 Billion Rupiah with a life sentence and below 1 Billion Rupiah with a penalty of 20 years in prison. Thus, we are confident and optimistic that corruption by itself will decline quite significantly.

In addition, it is necessary to establish an independent anticorruption body, a kind of Corruption Eradication Commission as it is today. Whose formation is carried out through the law and its structure is carried out up to the level of the Regency / City, with a large and broad authority in dealing with corruption, and its members consist of independent and professional people. Both from the ordinary people, executives, legislative and judiciary who have integrity and have a high commitment to corruption eradication in Indonesia. Do not even like today, namely the government together with the House of Representatives conducts a dosing because it cuts the special authorities owned by Corruption Eradication Commission as enshrined in the recent Corruption Eradication Commission law, [14]. In addition, the people who fill the institution are just an agreement between the government and the House Representatives that has the same interests that is to avoid the deterrent of the law. Whereas the government should not be, like that if indeed the government has a high commitment to the efforts to eradicate 
corruption in Indonesia. It should take a repressive effort in the suppression of corruption crimes so that anyone deters if they want to commit acts of corruption.

Mass media both print and electronic also need to be given more freedom, as a controller to prevent those who want to commit corruption first think twice, because of the risk that the media will expose their actions so that all people know it. In addition, it is also necessary to grow non-governmental organizations such as ICW and others, which are able to be controller's actions of officials and governments to prevent leakage of state budgets, so that the potential for corruption can be reduced.

It is necessary to dig back into the eastern culture (Indonesia) that has begun to be eroded by globalization, namely the culture of shame and responsibility for all its deeds, and should be given social punishment as shock therapy in order for the perpetrators to deter. In addition, it needs to be anti-corruption education with the aim of raising public awareness about the impact of corruption, inviting the public to engage in the movement to eradicate corruption and build anti-corruption behavior and culture from an early age. So that the people can also sue for feeling harmed. In addition, it needs to be a change in the political system that is more democratic and transparent, so that all actions and policies made by the government get the full support of all the people. In this way, it is expected that corruption in Indonesia will begin to erode and over time will become a culture of society in countering this act of corruption.

\section{Conclusion}

According the condition explaining above, the nation today which is always wrapped up with a disease called corruption, then the government and society are encouraged to take harsh or radical measures to overcome it, namely by fundamentally changing the strategy carried out to eradicate corruption as done in other countries. The radical strategy is determined institutional strategy. This strategy is carried out by carrying out systematic and coordinated actions with all relevant parties, in order to not only detect, educate early and punish the corruptors, but also to find out what causes corruption.

Through this action, it is hoped that the efforts to eradicate corruption carried out on the earth of Indonesia can achieve the results, as we want, so that in time the country and its government will actually be able to make this nation into a country that is safe, peaceful and prosperous.

\section{References}

[1] Pemerintah Republik Indonesia, Ketetapan MPR RI Nomor XI/MPR/1998. Indonesia, 1998.

[2] Pemerintah Republik Indonesia, UNDANG-UNDANG REPUBLIK INDONESIA NOMOR 28 TAHUN 1999 TENTANG PENYELENGGARAAN NEGARA YANG BERSIH DAN BEBAS DARI KORUPSI, KOLUSI, DAN NEPOTISME. Indonesia, 1999, p. 18.

[3] Pemerintah Republik Indonesia, UU No. 31 Tahun 1999 Undang-undang (UU) tentang Pemberantasan Tindak Pidana Korupsi. indonesia: https://peraturan.bpk.go.id/Home/Details/45350/uu-no-31-tahun-1999, 1999.

[4] Pemerintah Republik Indonesia, Undang- Undang Nomor 20 Tahun 2001 tentang 
Pemberantasan Tindak Pidana Korupsi. 2001.

[5] Pemerintah Republik Indonesia, UNDANG-UNDANG REPUBLIK INDONESIA NOMOR 15 TAHUN 2002 TENTANG TINDAK PIDANA PENCUCIAN UANG. 2002, p. 15.

[6] Presiden Republik Indonesia, KEPUTUSAN PRESIDEN REPUBLIK INDONESIA (KEPPRES) NOMOR 127 TAHUN 1999 (127/1999) TENTANG PEMBETUKAN KOMISI PEMERIKSA KEKAYAAN PENYELENGGARA NEGARA DAN SEKRETARIAT JENDERAL KOMISI PEMERIKSA KEKAYAAN PENYELENGGARA NEGARA. Indonesia, 1999, p. 13.

[7] Pemerintah Republik Indonesia, undang-undang nomor 19 tahun 2020 tentang KPK. Indonesia, 2020, p. 46.

[8] R. Dawkins, "UNDANG-UNDANG REPUBLIK INDONESIA NOMOR 30 TAHUN 2002 TENTANG KOMISI PEMBERANTASAN TINDAK PIDANA KORUPSI," KOMISI PEMBERANTASAN TINDAK PIDANA KORUPSI DENGAN. 2002.

[9] Juni Sjafrien Jahja, Say no to korupsi. Jakarta: VisiMedia, 2012.

[10] H. C. Black, “A Dictionary of Law,” Yale Law J., 1891, doi: 10.2307/783720.

[11] Pemerintah Republik Indonesia, PERATURAN PEMERINTAH PENGGANTI UNDANG-UNDANG (PERPU) NOMOR 24 TAHUN 1960. Indonesia, 1960, p. 17.

[12] Presiden Republik Indonesia, "Undang Undang Republik Indonesia No. 20 tahun 2001 tentang Perubahan atas Undang-undang No. 31 tahun 1999 tentang tindak tidana Korupsi, 2001.

[13] Pemerintah Republik Indonesia, PEMBERANTASAN TINDAK PIDANA KORUPSI Undang-Undang No. 3 Tahun 1971 Tanggal 29 Maret 1971. Indonesia, 1971, p. 19.

[14] Pemerintah Republik Indonesia, UNDANG-UNDANG REPUBLIK INDONESIA NOMOR 19 TAHUN 2019 TENTANG PERUBAHAN KEDUA ATAS UNDANGUNDANG NOMOR 30 TAHUN $20 O 2$ TENTANG KOMISI PEMBERANTASAN TINDAK PIDANA KORUPSI. Indonesia, 2019, p. 46.

[15] J. V. Henderson and A. Kuncoro, "Corruption in Indonesia," NBER Work. Pap. Ser., 2004, doi: 10.3386/w10674.

[16] S. Isra, Yuliandri, F. Amsari, and H. Tegnan, "Obstruction of justice in the effort to eradicate corruption in Indonesia," Int. J. Law, Crime Justice, 2017, doi: 10.1016/j.ijlcj.2017.07.001. 